Printed ISSN : $2406-7415$

Electronic ISSN : $2655-9919$

DOI: http://dx.doi.org/10.35137/jabk.v8i2.540

Jurnal Akuntansi dan Bisnis Krisnadwipayana

Volume 8 No. 2 (Mei - Agustus) 2021

\title{
PENGARUH PROFITABILITAS, PAJAK PENGHASILAN DAN UKURAN PERUSAHAAN TERHADAP KEPUTUSAN TRANSFER PRICING
}

\author{
Nadia Zalviana ${ }^{1}$ \\ Fakultas Ekonomi Universitas Krisnadwipayana \\ Jalan Unkris Jatiwaringin Jakarta Timur \\ Handphone Penulis : 085886769412, e-mail: nadiazalviana@gmail.com \\ Munawaroh $^{2}$ \\ Fakultas Ekonomi Universitas Krisnadwipayana \\ Jalan Unkris Jatiwaringin Jakarta Timur \\ Handphone Penulis : 081310258103, e-mail: munawaroh@unkris.ac.id
}

\begin{abstract}
This research examined the effects of profitability, income tax, and company size on transfer pricing decisions in agricultural and mining sector companies listed on Indonesia Stock Exchange (IDX) in the period of 2016 to 2018. The sampling technique chosen was by purposive sampling method, thus, 42 samples were selected. Hypothesis testing used logistic regression analysis. As a result, this study found that onlyby partiallycompany size has a significant effect on transfer pricing decisions.
\end{abstract}

Keywords: Transfer Pricing, Profitability, Income Tax, Company Size

\section{PENDAHULUAN}

Berkembangnya dunia usaha saat ini mendorong tumbuhnya perusahaan-perusahaan multinasional yang lingkup operasionalnya tidak hanya di negara sendiri, tetapi juga merambah ke mancanegara. Semakin pesatnya pertumbuhan ekonomi internasional turut mendorong berkembangnya perusahaan multinasional. Salah satu alasan yang mendasari berkembangnya perusahaan multinasional adalah karena adanya perbedaan tarif pajak yang berlaku di tiap-tiap negara. Hal ini memungkinkan perusahaan multinasional melakukan transfer pricing, yaitu memindahkan labanya ke negara dengan tarif pajak yang rendah, sehingga dapat memperkecil beban pajak sebagai upaya dalam memaksimalkan keuntungan Kurniawan (2015). Semakin berkembangnya jaman membuat perusahaan sering kali memanfaatkan transfer pricing agar dapat meminimalkan beban pajak yang harus dibayarkan (Mangoting, 2000: 80).

Undang-Undang Nomor 7 Tahun 1983 sebagaimana telah diubah terakhir dengan Undang-Undang Nomor 36 Tahun 2008 tentang Pajak Penghasilan, dalam pasal 18 mengatur masalahtransfer pricing mencakup beberapa hal, yaitu: pengertian hubungan istimewa, wewenang menentukan perbandingan utang dan modal, dan wewenang untuk melakukan koreksi dalam hal terjadi transaksi yang tidak memenuhi prinsip kewajaran dan kelaziman usaha( $\mathrm{arm}$ 's length principle), sehingga diatur dalam Peraturan Direktorat Jenderal Pajak No. 32 Tahun 2011, bahwa transaksi yang dilakukan dengan pihak istimewa harus sesuai dengan prinsip tersebut. 
Printed ISSN : $2406-7415$

Electronic ISSN : 2655 - 9919

Jurnal Akuntansi dan Bisnis Krisnadwipayana Volume 8 No. 2 (Mei - Agustus) 2021

Fenomena transfer pricingmenarik untuk diteliti, antara lain dikaitkan dengan beban pajak, ukuran perusahaan, profitabilitas.Hasil penelitian Dicky dan Raisa (2017) menunjukkan bahwa beban pajak berpengaruh positif terhadap transfer pricing dan ukuran perusahaan berpengaruh negatif terhadap transfer pricing. Sedangkan Sulistyowati dan R Kananto (2018), menunjukkan hasil yang diperoleh ukuran perusahaan memiliki pengaruh positif dan signifikan terhadap transfer pricing dan pajak berpengaruh positif namun tidak signifikan terhadap transfer pricing.Hasil penelitian Anisa dan Naniek (2018), menunjukkan bahwa pajak dan profitabilitas berpengaruh positif pada keputusan perusahaan dalam melakukan transfer pricing.

Praktik transfer pricing dalam komoditas yang harganya diatur oleh pemerintah seperti di sektor batubara, akan mudah menjadi temuan pajak.Oleh karena itu sektor pertanian dan pertambanganmenarik untuk diteliti. Kasus transfer pricingpada tahun 2018 dibandingkan dengan tahun 2017 meningkat cukup signifikan. Laporan yang mencangkup 89 yuridiksi 2018 Mutual Agreement Procedure (MAP) Statistics, Organization for Economic Co-operation and Development (OECD) mencatat jumlah sengketa transfer pricing naik $20 \%$, lebih tinggi dibandingkan dengan sengketa lainnya yang menunjukkan $10 \%$.

(https://ekonomi.bisnis.com/read/20190918/259/ 1149724/oecd-kasus-transfer-pricingmeningkat).

\section{LANDASAN TEORI}

\section{Transfer Pricing}

Menurut Gunadi (2007) transfer pricing adalah penentuan harga atau imbalan sehubungandengan penyerahan barang, jasa atau pengalihan teknologi antar perusahaan yang memiliki hubungan istimewa. Suandy(2011) menyatakan, bahwatransfer pricing digunakan untuk meminimalkan beban-beban pajak, pengendalian devisa, dan berkenaaan dengan risiko pengambilalihan oleh pemerintah asing.

Transfer Pricingdikemukakan oleh Horngren (2012) adalah jumlah yang dibebankan oleh satu segmen organisasi untuk produk yang dipasok ke segmen lain dari organisasi yang sama di perusahaan multinasional, dan transfer pricing digunakan untuk meminimalkan pajak penghasilan dan bea impor di seluruh dunia.

\section{Profitabilitas}

Menurut Kasmir (2013) profitabilitas merupakan rasio untuk menilai kemampuan perusahaan dalam mencari keuntungan. Rasio ini juga memberikan ukuran tingkat efektivitas manajemen suatu perusahaan. Hal ini ditunjukkan oleh laba yang dihasilkan dari penjualan dan pendapatan investasi. Penggunaan rasio ini adalah untuk menunjukkan tingkat efisiensi perusahaan.

Ada beberapa jenis rasio profabilitas yang digunakan untuk mengukur kemampuan perusahaan dalam menghasilkan laba atau keuntungan atas asset yang digunakan dalam perusahaan salah satunya adalah Return On Assets (ROA). Menurut Kasmir (2013) Return On Assets (ROA) adalah Rasio yang menunjukkan hasil 
DOI: http://dx.doi.org/10.35137/jabk.v8i2.540

(return) atas jumlah asset yang digunakan dalam perusahaan.

\section{Pajak Penghasilan}

Menurut Undang-Undang No.16 Tahun 2009 tentang Ketentun Umum dan Tata Cara Perpajakan, pajak adalah kontribusi wajib kepada negara yang terutang oleh orang pribadi atau badan yang bersifat memaksa berdasarkan Undang-Undang, dengan tidak mendapatkan imbalan secara langsung dan digunakan untuk keperluan negara bagi sebesar-besarnya kemakmuran rakyat.

Menurut Pernyataan Standar Akuntansi Keuangan (PSAK) No. 46 tentang Pajak Penghasilan bertujuan untuk mengatur perlakuan akuntansi untuk Pajak Penghasilan, yaitu cara mempertanggungjawabkan konsekuensi pajak pada periode berjalan dan periode mendatang untuk nilai tercatat aset yang diakui pada neraca perusahaan atau pelunasan nilai tercatat kewajiban yang diakui pada neraca perusahaan dan transaksitransaksi atau kejadian-kejadian lain pada periode berjalan yang diakui pada laporan keuangan perusahaan.

\section{Ukuran Perusahaan}

Menurut Brigham dan Houston (2009) ukuran perusahaan adalah rata-rata total penjualan bersih untuk tahun yang bersangkutan sampai beberapa tahun. Dalam hal ini penjualan lebih besar daripada biaya variabel dan biaya tetap, maka akan diperoleh jumlah pendapatan sebelum pajak. Sebaliknya jika penjualan lebih kecil daripada biaya variabel dan biaya tetap maka perusahaan akan menderita kerugian.
Printed ISSN : $2406-7415$

Electronic ISSN : 2655 - 9919

Jurnal Akuntansi dan Bisnis Krisnadwipayana Volume 8 No. 2 (Mei - Agustus) 2021

Menurut Hill (2003) Perusahaan multinasional didefinisikan sebagai perusahaan yang memiliki aktivitas produksi di dua negara atau lebih. Sartono(2012) menegaskan perusahaan multinasional (MNC) merupakan suatu perusahaan yang melakukan kegiatan produksi barang-barang kebutuhan konsumen dan memasarkan produk maupun jasanya ke dua negara atau lebih. Umumnya perusahaan multinasional mempunyai kantor pusat disuatu negara namun didukung oleh beberapa anak perusahaan dibeberapa negara.

\section{Kerangka Konseptual}

Konsep teori yang telah diuraikan di atas dapat digambarkan kerangka pemikiran penelitian kemungkinan terjadinya transfer pricingdalam gambar 1 dengan kerangka model penelitiannya dalam gambar 2 :

Gambar 1. Kerangka Pemikiran

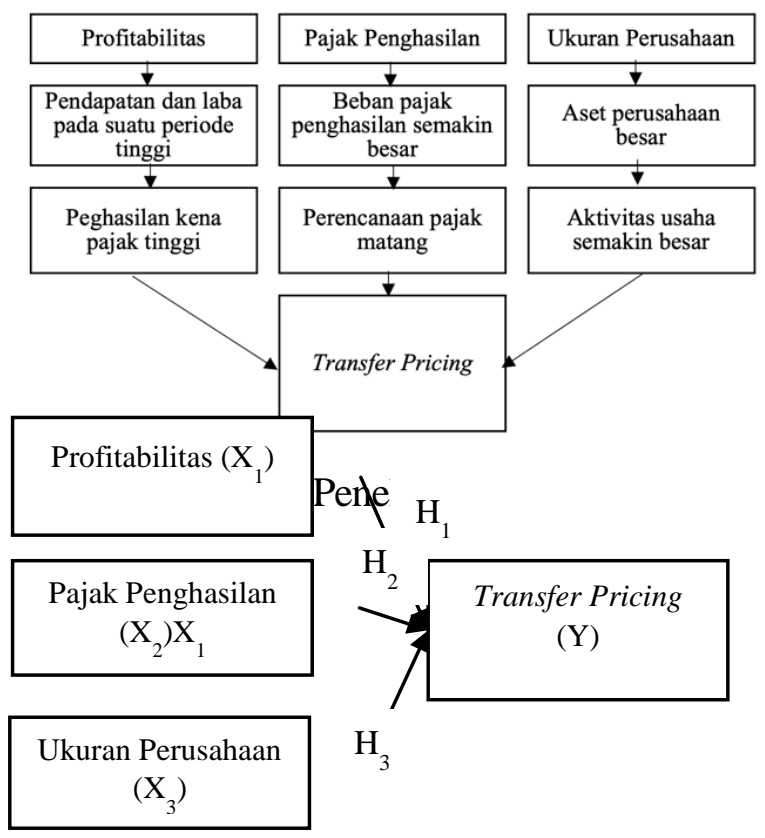

218

Copyright (c) 2021 Munawaroh, Munawaroh, SE., Ak., MM., CA., CSRS. , Nadia Zalviana. 
Printed ISSN : $2406-7415$

Electronic ISSN : 2655 - 9919

Jurnal Akuntansi dan Bisnis Krisnadwipayana Volume 8 No. 2 (Mei - Agustus) 2021

\section{Pengembangan Hipotesis}

Pengaruh profitabilitas terhadap transfer pricing

Menurut Anisa dan Naniek (2018), profitabilitas berpengaruh terhadap transfer pricing semakin tinggi tingkat profitabilitas suatu perusahaan maka semakin besar insentif perusahaan dalam melakukan praktik transfer pricing.Sebagaimana hasil penelitian tersebut, profitabilitas yang diproksikan dengan ROA berpengaruh positif pada keputusan perusahaan dalam melakukan transfer pricing, maka juga dihipotesiskan:

H1: Profitabilitas berpengaruh terhadap transfer pricing.

\section{Pengaruh pajak penghasilan terhadap} transfer pricing

Klassen et al, (2013) menemukan bahwa terjadi pergeseran pendapatan yang menjadikan pajak berpengaruh terhadap transfer pricing.Perusahaan multinasional memberi respon terhadap tingkat perubahan pajak di Kanada, Eropa, dan Amerika Serikat. Perusahaan multinasional menggeser pendapatan dari Kanada ke AS, sedangkan penurunan tarif pajak di Eropa menggeser pendapatan dari AS ke Eropa.

Sebagaimanahasil penelitian Aida, Nurul dan Rulfah (2019), bahwa pajak berpengaruh signifikan terhadap penerapan transfer pricing, maka dalam penelitian ini juga dihipotesiskan:

H2: Pajak penghasilan berpengaruh terhadap transfer pricing.

\section{Pengaruh ukuran perusahaan terhadap transfer pricing}

Semakin besar ukuran perusahaan, perusahaan tersebut memiliki aktivitas usaha dan transaksi keuangan yang semakin besar dimana kemungkinan terjadinya transfer pricing akan lebih tinggi terjadi di perusahaan besar dibandingkan perusahaan kecil (Ramadhandan Kustiani 2017). Hal ini didukung oleh beberapa penelitian terdahulu yang dilakukan oleh Sulistyowati dan R. Kananto (2018) sertaAfifah, Azwardi dan Luk Luk (2019) menunjukkan ukuran perusahaan positif terhadap transfer pricing.

Sebagaimana hasil penelitian Dicky dan Raisa (2017), ukuran perusahaan berpengaruh negatif signifikan terhadap praktik transfer pricing, maka dalam penelitian ini juga dihipotesiskan:

H3: Ukuran perusahaan berpengaruh terhadap transfer pricing

\section{METODE PENELITIAN}

\section{Populasi dan sampel}

Perusahaan sektor pertanian dan pertambangan yang terdaftar di Bursa Efek Indonesia (BEI) periode 2016-2018 sebanyak 61 perusahaan, merupakan populasipenelitian ini. Teknik pengambilan sampel menggunakanPurposive Sampling dengan kriteria yaitu perusahaan sektor pertanian dan pertambangan yang selama periode pengamatan berturut-turut mempublikasikan laporan keuangan di Bursa Efek Indonesia (BEI), tidak mengalami kerugian selama periode pengamatan dan laporan keuangan perusahaan sampel tidak disajikan dalam mata uang asing dan yang memenuhi kelengkapan data yang diperlukan 
Printed ISSN : $2406-7415$

Electronic ISSN : 2655 - 9919

Jurnal Akuntansi dan Bisnis Krisnadwipayana Volume 8 No. 2 (Mei - Agustus) 2021

untuk pengukuran variabel-variabel yang digunakan. Berdasarkan kriteria tersebut diperoleh14 perusahaan sebagai sampel, sehingga dalam 3 tahun yaitu tahun 20162018 diperoleh 42 data pengamatan.

\section{Jenis Data dan Teknik Pengumpulan Data}

Penelitian menggunakan data sekunder berupa laporan keuangan. Teknik pengumpulan data menggunakan teknik dokumentasi dengan mengumpulkan data laporan keuangan dari situs Bursa Efek Indonesiawww.idx.co.id dan www.sahamok.com.

\section{Teknik Analisis Data}

Analisis data dalam penelitian ini menggunakan teknik analisis kuantitatif, yaitu analisis model logit atau regresi logistik (logistic regression) dengan bantuan program IBM Statistical Package for Social Sciences (SPSS) versi 25. Metode regresi logistik digunakan karena variabel dependen dalam penelitian ini bersifat dikotomi atau dummy yaitu dinilai 1 (satu) jika melakukan penjualan kepada pihak yang memiliki hubungan istimewa dan jika sebaliknya dinilai 0 (nol). Metode analisis regresi logistik (logistic regression) tidak memerlukan asumsi normalitas data dalam variabel bebasnya (Ghozali, 2018:323).

Persamaan model dalam penelitian ini sebagai berikut: $Y=\alpha+\beta_{1} \chi_{1}+\beta_{2} \chi_{2}+\beta_{3} \chi_{3}+\varepsilon$ Keterangan:

$\mathrm{Y}=$ Transfer Pricing $(\mathrm{TP})$

$\alpha=$ konstanta

$\beta=$ koefisien regresi

$\mathrm{X}_{1}=$ Profitabilitas, diukur dengan nilai ROA, yaitu Earning After Interest and Tax dibagi total asset.
$\mathrm{X}_{2}=$ Pajak Penghasilan, diukur dengan nilai effective tax rate(ETR), yaitu hasil pengurangan beban pajak dengan pajak tangguhan dibagi laba kena pajak.

$\mathrm{X}_{3}=$ Ukuran Perusahaan (UKP), diukur dengan logn total asset

$\varepsilon=$ koefisien error

\section{HASIL PENELITIAN DAN PEMBAHASAN}

Sebelum dilakukan pengujian regresi logistik, terlebih dahulu dilakukan uji statistik deskriptif untuk mendeskripsikandata penelitian ini yaitu dilihat dari nilai rata-rata (mean), standar deviasi, maksimum, dan minimum(Ghozali 2018). Berikut ini hasil ujistatistik deskriptif dengan 42 data pengamatan untuk masing-masing variabel yang digunakan dalam penelitian ini:

Tabel 1.Hasil Uji Statistik Deskriptif

\begin{tabular}{lllll}
\hline \multicolumn{1}{c}{ Variabel } & Min & Maks & Mean & $\begin{array}{l}\text { Std. } \\
\text { Dev. }\end{array}$ \\
\cline { 1 - 2 } Transfer pricing $(Y)$ & 0 & 1 & 0,5 & 0,506 \\
Profitabilitas $\left(X_{1}\right)$ & 0,002 & 0,212 & 0,051 & 0,046 \\
Pajak Penghasilan $\left(X_{2}\right)$ & 0,455 & 2,185 & 0,454 & 0,398 \\
Ukuran Perusahaan $\left(X_{3}\right)$ & 26,518 & 31,137 & 29,576 & 1,390 \\
\hline Sumber:output SPSS
\end{tabular}

Transfer pricing (Y), oleh karena merupakan data dikotomi, maka nilai minimum sebesar 0,0000, nilai maksimum sebesar 1,000, dan nilai rata-rata(mean) sebesar 0,500, serta nilai standar deviasi sebesar 0,5061.

Profitabilitas $\left(X_{1}\right)$ menunjukkan nilai minimumnya sebesar 0,0022 , nilai maksimum sebesar 0,2119 dengan mean sebesar 0,051205 dannilai standar deviasi sebesar 0,0456070.

Pajak penghasilan $\left(X_{2}\right)$ memiliki nilai minimum sebesar 0,455 , nilai maksimum 
Printed ISSN : $2406-7415$

Electronic ISSN : 2655 - 9919

Jurnal Akuntansi dan Bisnis Krisnadwipayana Volume 8 No. 2 (Mei - Agustus) 2021

sebesar 2,1853, nilai mean sebesar 0,453936, serta nilai standar deviasi sebesar 0,3982257.

Ukuran Perusahaan $\left(X_{3}\right)$ nilai minimum sebesar 26,5185, maksimum sebesar 31,1368, mean sebesar 29,575650, serta standar deviasi sebesar 1,3902022.

Dengan demikian seluruh variabel memiliki nilai mean lebih besar dari nilai standar deviasi, artinya penyimpangan data yang terjadi rendah, maka penyebaran nilainya merata.

\section{Analisis Regresi Logistik}

Berikut ini hasil uji setiap tahap dalam pengujian regresi logistik.

\section{Hasil Uji Kesesuaian Keseluruhan Model (Overall Model Fit)}

Pengujian ini dilakukan untuk mengetahui apakah model fit dengan data yang sebelum maupun setelah variabel independen dimasukan ke dalam model. Pengujian dilakukan dengan membandingkan nilai antara $-2 \quad \log$ Likelihood (-2LL) pada awal (Block Number=0) dengan nilai -2 Log Likelihood (-2LL) pada akhir (Block Number =1). Adanya penurunan nilai -2LL menunjukkan bahwa model regresi yang baik atau model yang dihipotesiskan fit dengan data. Berikut ini disajikan datahasil uji kesesuaian keseluruhan model:

Tabel 2.Hasil Uji Kesesuaian Keseluruhan Model

\begin{tabular}{lc}
\hline \multicolumn{3}{c}{ Perbandingan -2Log Likelihood Awal dan Akhir } \\
\hline -2Log Likelihood (-2LogL) pada awal c & 58,224 \\
-2Log Likelihood (-2LogL) pada akhir & 30,352
\end{tabular}

Berdasarkan tabel 2 menunjukkan bahwa nilai awal model yang memasukkan konstanta mempunyai nilai -2LL sebesar 58.224. Sedangkan pada nilai akhir mengalami penurunan setelah masuknya beberapa variabel independen dalam penelitian, nilai -2LL menjadi 30.352. Penurunan ini menunjukkan bahwa model regresi yang baik dengan kata lain model yang dihipotesiskan fit, artinya penambahan variabel independen yaitu profitabilitas, pajak penghasilan, dan ukuran perusahaan akan memperbaiki model fit penelitian ini.

\section{Hasil Uji Koefisien Determinasi}

Koefisien determinasi digunakan untuk mengetahui seberapa besar variabilitas variabel-variabel independen mampu memperjelas variabel-variabel dependen. Koefisien determinasi pada regresi logistik dapat dilihat pada nilai Nagelkerke $R$ Square. Berikut hasil pengujian koefisien determinasi:

Tabel 3. Hasil Uji Koefisien Determinasi

\begin{tabular}{cccc}
\multicolumn{4}{c}{ Model Summary } \\
\hline Step & $\begin{array}{c}-2 \text { Log } \\
\text { Likelihood }\end{array}$ & $\begin{array}{c}\text { Cox \& } \\
\text { Snell R } \\
\text { Square }\end{array}$ & $\begin{array}{c}\text { Nagelker } \\
\text { ke R } \\
\text { Square }\end{array}$ \\
\hline 1 & 30,352 & 0,485 & 0,647 \\
\hline
\end{tabular}

Sumber: Output SPSS

Berdasarkan tabel 3 menunjukkan bahwa nilai Nagelkerke $R$ Square adalah 0,647 yang berarti variabel yang dependen dapat dijelaskan oleh variabel independen seperti profitabilitas, pajak penghasilan dan ukuran perusahaan adalah sebesar $64,7 \%$ dan sisanya sebesar $35,3 \%$ dijelaskan oleh variabel-variabel lain seperti leverage (Anisa, 2018), exchange rate (Anisa,2018), 
Printed ISSN : $2406-7415$

Electronic ISSN : 2655 - 9919

Jurnal Akuntansi dan Bisnis Krisnadwipayana Volume 8 No. 2 (Mei - Agustus) 2021

kepemilikan asing (Dicky,2017) serta variabel-variabel lain diluar model penelitian ini.

\section{Hasil Uji Kelayakan Model Regresi}

Hosmer and Lemeshow's Goodness of Fit Test digunakan untuk menilai kelayakan model regresi yang digunakan. Model ini untuk menguji hipotesis nol bahwa data empiris sesuai dengan model (tidak ada perbedaan antara model dengan data sehingga model dapat dikatakan fit (Ghozali, 2018: 329). Berikut ini disajikan data hasil pengujian kelayakan model regresi.

Tabel 4.Hasil Uji Kelayakan Model Regresi

\section{Hosmer and Lemeshow Test}

\begin{tabular}{cccc}
\hline Step & Chi-square & df & Sig. \\
\hline 1 & 4,995 & 8 & 0,758 \\
\hline
\end{tabular}

Sumber: output SPSS

Tabel 4 menunjukkan bahwa nilai ChiSquare sebesar 4,995 dengan signifikansi sebesar 0,758. Berdasarkan hasil tersebut, karena nilai signifikansi lebih besar dari 0,05 $(0.758>0,05)$ maka model dapat disimpulkan mampu memprediksi model observasinya atau model dapat dikatakan fit dengan data dan model dapat diterima sehingga model ini dapat digunakan untuk analisis selanjutnya.

\section{Hasil Uji Matriks Klasifikasi}

Matriks klasifikasi menunjukkan kekuatan prediksi dari model regresi untuk memprediksi kemungkinan perusahaan membuat keputusan transfer pricing. Tabel klasifikasinya menghitung estimasi yang benar (correct) dan salah (incorrect). Hasil uji matriks klasifikasi ditunjukkan pada tabel5 berikut ini:

Tabel 5.Hasil Uji Matriks Klasifikasi

\section{Classification Table}

\begin{tabular}{ccccc} 
& \multicolumn{3}{c}{ Predicted } \\
\hline & \multicolumn{3}{c}{ Transfer Pricing } & \\
\hline Observed & & 0,0 & 1,0 & $\begin{array}{l}\text { Percentag } \\
\text { e Correct }\end{array}$ \\
\hline Step 1 Transfer pricing & 0, & 15 & 6 & 71,4 \\
& 0 & 3 & 18 & 85,7 \\
Overall & 1, & & & 78,6 \\
percentage & 0 & & &
\end{tabular}

Sumber: output SPSS

Berdasarkan tabel 5 diatas menunjukkan bahwa kekuatan model regresi dalam memprediksi tingkat prediksi model adalah sebesar 78,6\%. Artinya kemampuan prediksi dari model dengan variabel profitabilitas, pajak penghasilan, dan ukuran perusahaan secara statistik memprediksi sebesar 78,6\%. Hasil uji menunjukkan $71,4 \%$ tidak adatransfer pricing dan $85,7 \%$ ada transaksi transfer pricing telah mampu diprediksi oleh model.

Kekuatan prediksi dari model regresi untuk memprediksi kemungkinan terjadinya transaksi pada pihak berelasi adalah sebesar $85,7 \%$. Hal ini menunjukkan bahwa dengan model regresi yang digunakan terdapat 24 perusahaan $(85,7 \%$ dari 42 perusahaan) diprediksi melakukan transfer pricing yang melakukan transfer pricing. Kekuatan prediksi model perusahaan yang dinyatakan tidak melakukan transaksi transfer pricing adalah sebesar 71,4\% yang berarti bahwa dengan model regresi yang digunakan terdapat 18 perusahaan yang tidak melakukan transaksi transfer pricing. Sehingga secara keseluruhan ketepatan klasifikasi sebesar 78,6\%. 
Printed ISSN : $2406-7415$

Electronic ISSN : 2655 - 9919

Jurnal Akuntansi dan Bisnis Krisnadwipayana Volume 8 No. 2 (Mei - Agustus) 2021

\section{Hasil Uji Hipotesis dan Model Regresi Logistik yang Terbentuk}

\begin{abstract}
Pengujian hipotesis dilakukan dengan cara membandingkan antara nilai probabilitas (sig) dan koefisien. Apabila angka signifikansi menunjukkan angka yang lebih kecil terlihat 0,05 maka koefisien regresi adalah signifikan pada tingkat $5 \%$. Hal tersebut berarti $\mathrm{H} 0$ ditolak dan $\mathrm{H} 1$ diterima, yang menunjukkan bahwa variabel independen berpengaruh secara signifikan terhadap terjadinya variabel dependen.

Hasil pengujian memberikan model regresi logistik yang terbentuk yang disajikan pada tabel dibawah ini:
\end{abstract}

Tabel 6. Hasil Uji Koefisiensi Regresi Logistik

\begin{tabular}{lrc}
\multicolumn{3}{c}{ Variables in the Equation } \\
\hline \multicolumn{1}{c}{ Variabel } & \multicolumn{1}{c}{ B } & Sig. \\
\hline Step 1 Profitabilitas $\left(X_{1}\right)$ & 20,756 & 0,202 \\
Pajak Penghasilan $\left(X_{2}\right)$ & $-2,025$ & 0,155 \\
Ukuran Perusahaan $\left(X_{3}\right)$ & 2,120 & 0,012 \\
Constant & $-63,520$ & 0,012 \\
\hline
\end{tabular}

Hasil pengujian terhadap koefisien regresi logistik menghasilkan model berikut ini:

$\mathrm{TP}=-63,520+20,756 X_{1}-2,025 X_{2}+2,120 X_{3}$

Berdasarkan tabel 6 tersebut di atas, maka hasil uji hipotesis dapat dijelaskan sebagai berikut:

Variabel profitabilitas sebagai variabel independen X1 memiliki koefisien regresi positif sebesar 20,756 dengan tingkat signifikansi 0,202 yang berada di atas 0,05 $(5 \%)$. Karena tingkat signifikansi lebih besar dari $\mathrm{a}=5 \%$ maka hipotesis kesatu (H1) ditolak yang berarti profitabilitas tidak berpengaruh terhadap keputusan transfer pricing.

Hasil analisis data tersebut menunjukkan bahwa profitabilitas terhadap transfer pricing berpengaruh positif namun tidak signifikan. Hasil penelitian ini sesuai dengan penelitian yang dilakukan oleh Nurul Afifah Agustina (2019). Pengaruh profitabilitas tidak signifikan pada keputusan perusahaan dalam melakukan praktik transfer pricing. Hal ini dapat diartikan bahwa perusahaan sektor pertanian dan pertambangan dengan tingkat profitabilitas tinggi maupun rendah memiliki kemungkinan yang sama dalam melakukan praktik transfer pricing.

Variabel pajak penghasilan sebagai variabel independen X2 memiliki koefisien regresi negatif sebesar -2,025 dengan tingkat signifikansi 0,155 yang berada di atas 0,05 $(5 \%)$. Karena tingkat signifikansi lebih besar dari $\mathrm{a}=5 \%$ maka hipotesis kedua $(\mathrm{H} 2)$ ditolak, yang berarti pajak penghasilan berpengaruh tidak signifikan terhadap keputusan transfer pricing.

Hasil penelitian ini didukung dengan penelitian sebelumnya antara lain Fendi Wahyu Nugroho, Yuli Chomsatu Samrotun, Anita Wijayanti (2020) bahwa pajak berpengaruh tidak signifikan terhadap transfer pricing. Hal tersebut dikarenakan perusahaan menjalankan manajemen pajak sesuaidengan peraturan perundang-undangan yang berlaku sehingga usaha meminimalisirbeban pajak perusahaan tidak mendorong perusahaan untuk melakukan transfer pricing.Demikian pula pada perusahaan sektor pertanian dan pertambangan yang telah terdaftar di BEI ini.

Variabel ukuran perusahaan (X3) memiliki koefisiensi regresi positif sebesar 2,120 dengan tingkat signifikansi 0,012 yang berada dibawah 0,05 (5\%). Karena tingkat signifikansi lebih kecil dari $a=5 \%$ maka 
Printed ISSN : $2406-7415$

Electronic ISSN : 2655 - 9919

Jurnal Akuntansi dan Bisnis Krisnadwipayana Volume 8 No. 2 (Mei - Agustus) 2021

hipotesis ketiga (H3) diterima yang berarti ukuran perusahaan berpengaruh terhadap keputusan transfer pricing.

Hasil penelitian ini didukung dengan hasil penelitian dari Sulistyowati dan $\mathrm{R}$ Kananto (2018) yang menyatakan bahwa ukuran perusahaan memiliki pengaruh positif dan signifikan terhadap transfer pricing. Dan sesuai dengan penelitian yang dilakukan oleh Ramadhan dan Kustiani (2017) yang menyatakan bahwa semakin besar ukuran perusahaan, perusahaan tersebut memiliki aktivitas usaha dan transaksi keuangan yang semakin besar dimana kemungkinan terjadinya transfer pricing akan lebih tinggi terjadi di perusahaan besar dibandingkan perusahaan kecil.

Hasil uji hipotesis variabel $\mathrm{X}$ terhadap variabel Y (Transfer Pricing)menggunakan metode regresi logistik, dirangkum dalam tabel 7:

Tabel 7. Hasil uji Hipotesis menggunakan Regresi Logistik

\begin{tabular}{|c|c|c|c|c|}
\hline Hipotesis & & Parsial & Hasil & Kesimpulan \\
\hline $\mathrm{H} 1$ & Profitabil & itas $\left(X_{1}\right)$ & 0.202 & ditolak \\
\hline $\mathrm{H} 2$ & Pajak & Penghasilan & 0,155 & ditolak \\
\hline $\mathrm{H} 3$ & $\left(X_{2}\right)$ & & 0,012 & diterima \\
\hline & $\begin{array}{l}\text { Ukuran } \\
\left(X_{3}\right)\end{array}$ & Perusahaan & & \\
\hline
\end{tabular}

\section{Hasil Uji Omnibust Test ofModel Coefficient}

Pengujian ini dilakukan untuk menguji secara simultan atas variabel independen apakah memiliki pengaruh terhadap variabel dependennya. Pengujian ini dilakukan berdasarkan pada nilai signifikansi sedangkan nilai Chi-square merupakan penurunan nilai -2 Log Likelihood. Apabila nilai signifikansi dalam pengujian ini lebih kecil dari tingkat signifikansi yaitu 5\% maka dapat disimpulkan bahwa penggunaan variabel independen dalam model penelitian secara simultan dapat memprediksi variabel dependen. Hasil dari Omnibust Test tersaji dalam tabel 8 berikut ini:

Tabel 8.Hasil Uji Koefisiensi Regresi Logistik

Omnibus Tests of Model Coefficients

\begin{tabular}{llrrc}
\hline & & Chi-square & df & Sig. \\
\hline Step 1 & Step & 27,872 & 3 & 0,000 \\
& Block & 27,872 & 3 & 0,000 \\
& Model & 27,872 & 3 & 0,000 \\
\hline
\end{tabular}

Berdasarkan hasil Omnibust Test of Model Coefficient yang disajikan dalam Tabel 8 diperoleh nilai signifikansi sebesar 0,000. Apabila nilai signifikansi dari hasil Omnibust Test of Model Coefficient dibandingkan dengan tingkat signifikansi yang digunakan yaitu sebesar 5\% maka tentunya nilai 0,000 lebih kecil dari 0,05 sehingga menunjukkan bahwa data dalam penelitian ini layak untuk digunakan dan penggunaan variabel independen dalam model penelitian ini secara simultan dapat memprediksi variabel dependennya.

\section{KESIMPULAN DAN SARAN}

\section{Kesimpulan}

Berdasarkan penelitian yang telah dilakukan dengan analisis regresi logistik dan pembahasan hasil pengujian, maka dapat diambil kesimpulan sebagai berikut:

1. Profitabilitas memiliki pengaruh positif namun tidak signifikan terhadap keputusan Transfer Pricing pada perusahaan sektor pertanian dan pertambangan yang terdaftar di BEI pada tahun 2016-2018. Hal tersebut menunjukkan jika profitabilitas 
Printed ISSN : $2406-7415$

Electronic ISSN : 2655 - 9919

Jurnal Akuntansi dan Bisnis Krisnadwipayana Volume 8 No. 2 (Mei - Agustus) 2021

mengalami kenaikan maka akan meningkatkan transfer pricing, namun kenaikan ini tidak berpengaruh signifikan terhadap keputusan transfer pricing.

2. Pajak Penghasilan memiliki pengaruh negatif dan tidak signifikan terhadap keputusan Transfer Pricing pada perusahaan sektor pertanian dan sektor pertambangan yang terdaftar di BEI pada tahun 2016-2018. Hal tersebut menunjukkan jika pajak penghasilan mengalami kenaikan maka akan mengalami penurunan pada transfer pricing dan kenaikan ini juga tidak berpengaruh signifikan terhadap transfer pricing.

3. Ukuran Perusahaan berpengaruh positif dan signifikan terhadap keputusan Transfer Pricing pada perusahaan sektor pertanian dan sektor pertambangan yang terdaftar di BEI pada tahun 2016-2018. Hal tersebut menunjukkan jika ukuran perusahaan mengalami kenaikan maka akan meningkatkan transfer pricing dan kenaikan ini juga berpengaruh signifikan terhadap keputusan transfer pricing.

\section{Saran}

Berdasarkan kesimpulan tersebut di atas, bahwa ukuran perusahaan berpengaruh positif dan signifikan terhadap transfer pricing, maka disarankan untuk beberapa pihak, antara lain:

1. Bagi perusahaan perlu hati-hati dalam mengambil keputusan transfer pricing, oleh karena akan dapatdiketahui kemungkinan perusahaan mengambil keputusan transfer pricing, antara lain dapat dilihat dari ukuran perusahaan sebagaimana hasil penelitian ini, yaitu semakin besar asset yang dimiliki semakin

\section{DAFTAR PUSTAKA}

Afifah Hazihah, Azwardi, dan Luk Luk Fuadah. (2019). The Effect Of Tax, Tunneling Incentive, Bonus Mechanisms, And Firm Size On Transfer Pricing (Indonesian Evidence).

Aida Yulia, Nurul Hayati, dan Rulfah M.Daud. (2019). The Influence of Tax, Foreign Ownership and Company Size on the Application of Transfer Pricing in Manufacturing Companies Listed on IDX during 2013-2017. International Journal of Economics and Financial.Issues, 2019, 9(3), 175-181.

Anisa Sheirina Cahyadi dan Naniek Noviarti. (2018). Pengaruh Pajak, Exchange Rate, Profitabilitas, Dan Leverage Pada Keputusan Melakukan Transfer Pricing, E-Jurnal Akuntansi Universitas Udayana. Brigham E.F dan Houston J.F. (2009).Essentials of Financial Management: Dasar Dasar Manajemen Keuangan, Penerjemah Ali Akbar Yulianto, Edisi Kesebelas, Edisi Indonesia, Buku I, Jakarta: Salemba Empat.

Copyright (c) 2021 Munawaroh, Munawaroh, SE., Ak., MM., CA., CSRS. , Nadia Zalviana. 
Printed ISSN : $2406-7415$

Electronic ISSN : 2655 - 9919

DOI: http://dx.doi.org/10.35137/jabk.v8i2.540

Dicky Suprianto dan Raisa Pratiwi. (2017).Pengaruh Beban Pajak, Kepemilikan Asing, dan Ukuran Perusahaan Terhadap Transfer Pricing Pada Perusahaan Manufaktur di Bursa Efek Indonesia (BEI) Periode 2013-2016, STIE Multi Data Palembang.

Direktorat Jenderal Pajak. (2008).UndangUndangRepublik Indonesia Nomor 36 tentang Pajak Penghasilan.

Direktorat Jenderal Pajak. (2009).UndangUndang Republik Indonesia No.16 tentang Ketentun Umum dan Tata Cara Perpajakan.

Ghozali, Imam. (2018).Aplikasi Analisis Multivariate dengan Program IBM SPSS 25. Semarang: BP Undip.

Gunadi. (2007).Pajak Internasional, Jakarta: Lembaga Penerbit Fakultas Ekonomi Universitas Indonesia

Hill, Charles W.L. (2003).International Business: Competing in the Global Marketplace, Fourth Edition, New York: McGraw-Hill.

Horngren, Charles T.Srikant M.Datar dan Madhav V.Rajan. 2012.Cost Accounting:A Managerial Emphasis, 14th Edition, New Jersey: Pearson Prentice Hall

Ikatan Akuntan Indonesia (IAI). (2013). Standar Akuntansi Keuangan, Jakarta: DSAK-IAI

Kasmir. 2013.Analisis Laporan Keuangan, Edisi 1, Cetakan ke-6, Jakarta : Rajawali Pers.

Klassen, K. J., Lisowsky, P., dan Mescall, D. (2013). Transfer pricing: Strategies, practices, and tax minimization. Practices, and Tax Minimization, Journal of International Economics.

Kurniawan, A. M. (2015).Transfer Pricing untuk Kepentingan Pajak, Yogyakarta: Andi Offset.
Jurnal Akuntansi dan Bisnis Krisnadwipayana Volume 8 No. 2 (Mei - Agustus) 2021

Mangoting. (2000).Aspek Perpajakan Dalam Transfer Pricing, Jurnal Akuntansi \& Keuangan.Vol. 2 No. 1, Mei 2000: 69 -82 .

Ramadhan, M.R., dan Kustiani, N.A. (2017). Faktor-Faktor Penentu Agresivitas Transfer Pricing. Pajak, Mekanisme Bonus dan Transfer Pricing. Jurnal Politeknik Negeri Jakarta

Sartono, R, Agus. (2012).Manajemen Keuangan Internasional, Edisi Pertama, Yogyakarta: BPFE.

Suandy, Erly. (2011).Perencanaan Pajak. Edisi 5. Jakarta: Salemba Empat

Sulistyowati Sulistyowati, dan R Kananto. (2018). The Influences of Tax, Bonus Mechanism, Leverage and Company Size Through Company Decision on Transfer Pricing. Advances in Economics, Business and Management Research. Volume 73

Copyright (c) 2021 Munawaroh, Munawaroh, SE., Ak., MM., CA., CSRS. , Nadia Zalviana. 